\title{
Business Opportunities and Sustainable Development
}

\author{
Ogunlade R Davidson
}

Energy and Development Research Centre, University of Cape Town

\begin{abstract}
The conventional development paradigm appears to have failed the poor regions of the world. It has led to a widening gap between rich and poor, while the world as a whole is getting richer. Attempts to integrate social and environmental concerns into the conventional development paradigm have led to the concept of sustainable development.
\end{abstract}

JEL $\mathrm{O} 13$

\section{INTRODUCTION}

Since the United Nations Conference on Environment and Development held in 1992 in Rio de Janeiro (the "Rio Conference", widely known as the "Earth Summit"), more people have seriously questioned the conventional development paradigm. This paradigm led to a high standard of living for a few countries and a small segment in the vast majority of countries, resulting in a widening gap between the rich and the poor. Of more concern is that while the gap continues to widen, the world as a whole is getting richer. This has triggered many issues since Earth Summit, among them the lack of integration of social and environmental concerns into the conventional development paradigm. This debate only reinforces the call for such integration which was made in the Brundtland Report of 1987, calling for changing our development path to a more sustainable one by including social and environmental concerns. Attempting to integrate these concerns led to the concept of sustainable development.

The growing gap between countries and regions, and different groups within countries, as indicated in Figurel, has led to even greater concern regarding the future of the world if these trends continue. Redressing this situation will call for participation and cooperation by the main stakeholders of development, including the business sector. Such participation will require new types of 
relationship between the different stakeholders. This issue will be dealt with later.

The skewness in incomes as demonstrated in Figure 1 is mainly due to historical circumstances that evolved between nations and the way management of production and consumption of goods and services resulted in a world divided into developed and developing countries. The former now has about a quarter of the world's population but 75 per cent of the world's income, while the remaining 75 per cent of the population receive 25 per cent of the income. The world economic system that emerged strengthened after the second world war only worsened the situation, because the gap got wider, although a few countries emerged with growing economies and increased incomes. This situation forms part of the ensuing discussion.

\section{Figure 1 World income distribution}

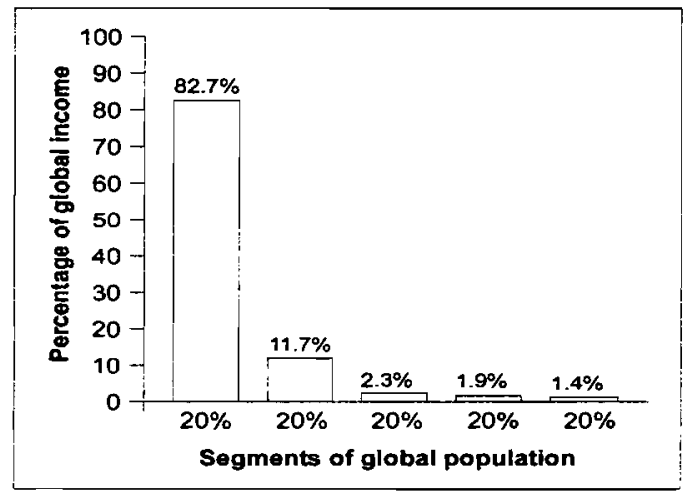

Countries can be classified into three types: first, those with developed production systems and markets, which are benefiting greatly from the gains of globalisation; second, countries with growing production systems and emerging markets, which have started gaining from globalisation; third, the 48 normally referred to as "least developed countries", which are suffering from increasing marginalisation and almost global market exclusion. All these country types have markets for goods and services produced with sustainable development objectives in mind, but the greatest market is in the last group because they are ready to satisfy their urgent developmental needs and are also flexible enough to adjust to a new developmental paradigm. Because of their urgent needs, these countries have the opportunity to take off with a development path that reflects the principles of social equity, feasible economy and efficient markets. 
The private sector can contribute in this task of developing countries by assisting with market stimulation as this will provide the opportunity of benefiting from early market entry. Providing environmentally and socially sound goods and services offers a business opportunity because it not only widens the market, but also provides the means for eaming goodwill from consumers. Therefore, the challenge for the business sector is to cooperate with other stakeholders in establishing markets in the least developed countries, promoting markets in emerging countries, and maintaining markets in developed countries. Maximising this potential will show that sustainable development can also mean good business.

\section{RIO EXPERIENCE AND AGENDA 21}

At the 1992 Rio Conference, over 100 heads of state signed and agreed to a blueprint for sustainable development, known as Agenda 21, and also to two main global Conventions, one on biodiversity (CBD) and the other on climate change (UNFCCC). This was a clear manifestation of willingness to achieve the various components of the agreements arrived at in Rio. A feature common to all these agreements was the search for alternative development paths that include social and environmental concerns as well as economic ones, while not sacrificing national and regional development aspirations. In addition, these documents, especially Agenda 21, address issues of major concern to a wide range of countries - including growing poverty and over-consumption, and how these impact on the world's resources. The Conventions also deal with poverty, hunger, disease, illiteracy, and the continued deterioration of global and national ecosystems. Coping with these challenges will require an increase in many goods and services, using growth paths that depart from past practices.

Many new and laudable ideas for international cooperation and financing were agreed upon at the Earth Summit. These include the financial resources required to implement Agenda 21 at national level. The spirit of consensus and political commitment led to donor countries agreeing to contribute up to 0.7 per cent of their GDP to finance overseas development assistance. Further, issues of debt management, and creating a climate for attracting foreign investments in developing countries, were also agreed on. However, events that followed show that this spirit of cooperation did not continue.

\section{DEFINING SUSTAINABLE DEVELOPMENT}

Sustainable development has attracted several definitions because of various interest groups' different perspectives. In the Brundtland report, it is defined as 
"a development that meets the present needs and goals of the population while not compromising the ability of the future generation meeting theirs", and, with some variations, the academic community largely accepts this definition. The business sector, though, has a different definition, because their interests differ significantly from those of academics and community development workers. The International Institute for Sustainable Development defines sustainable development relating to the business sector as "adopting business strategies and activities that meet the needs of the enterprise and its stakeholders today, while protecting, sustaining and enhancing the human and natural resources that will be needed in the future". Here, there is clearly a central concerned about shareholder value, in addition to other aspects of sustainable development.

\section{CHANGING TRENDS IN CUSTOMER BEHAVOUR}

As suggested before, there is a large market for environmentally sound goods and services in all countries that the business sector can take advantage of. Benefiting from this market potential will, however, require recognition of the changing trends in all these countries, although there is variation depending on regional and local situations. The following provides some idea, though not exhaustively, about the changing trends in customer behaviour of which businesses should be mindful.

- There is a growing awareness of environmental hazards, simply because the impacts of local and regional environmental problems are becoming more vivid. Also, impacts of climate variability in the form of extreme events, such as droughts and cyclones, are more regular and pervasive. The healthrelated consequences of pollution in rapidly growing cities could easily be seen in many places, while people living in cities that appear to have managed pollution are concerned about maintaining such gains.

- Many people are increasingly accepting that partnership among stakeholders in development is a preferred strategy for achieving future development goals. Past strategies that were largely based on "do it alone" or "merging" to take control have largely failed to deliver the expected results - and when they succeed, only a few have benefited.

- There is a growing call for accountability, transparency and consultation in many sectors, including the business sector, as people become increasingly educated and exposed to high quality literature. Also, the results of not abiding by these principles are damaging, and awareness of this is becoming widespread.

- Governments worldwide increasingly demand detailed reporting by operating institutions, including the business sector, and suitable mechanisms are being instituted to ensure that it is done. Similar demands 
are also increasingly coming from civil society, the usual watchdog for such operations, as it becomes more organised.

- The desire for environmentally sound goods, commonly known as "green products" is growing, especially in rich countries.

\section{CHANGING ENVIRONMENT IN THE BUSINESS SECTOR}

A major recent change that has taken place outside business institutions is the attitude of governments towards business, seeing it as a partner in development and not as a competitor in providing services. Recent events in the global political scene have led many to believe in the option of joint public/private collaboration as a way forward in promoting development, including areas that were traditionally the domain of the public sector. There is now increasing participation by the private sector in infrastructure investments, including energy and water. In addition, the private sector is now fully involved in social investments (though the results have been mixed), including building roads, operating railways and even in some cases, owning and operating prisons.

Another change is the development of an organisation within the business sector that promotes sustainable development and environment concerns as business activities: the World Business Council for Sustainable Development (WBCSD). This is a coalition of some 120 international companies, covering 35 countries in a wide range of sub-sectors, that share a common commitment to the environment, economic growth and sustainable development. They play an important role in developing closer ties between business, governments and civil society, and promote high standards of environmental management in business organisations. There are signs that this organisation is not only growing in membership and coverage, but is also enjoying increased status especially with governments, as they now hold joint activities such as seminars and workshops with governments. One WBCSD activity of direct relevance to sustainable development is around the principle of "social responsibility". This mainly involves creating sustainable development networks that promote social responsibility among business operations. The membership of this network is steadily growing, which demonstrates commitment to the ideals of sustainable development.

In addition to WBCSD, a group of large multi-national companies have entered into a "global compact" with the Secretary-General of the United Nations, aimed at establishing an official relationship between the business sector and the UN for joint activities and other forms of collaboration in their common interests. 


\section{INTEGRATING SUSTAINABLE DEVELOPMENT IN BUSINESS}

Integrating the main objectives of sustainable development, including social and environmental concerns, poses serious challenges to the business sector because of the traditional role of business - that is, maximising shareholder value. These challenges can be summarised as follows:

- The responsibility for protecting social and environmental concerns has been the government's, with assistance from community groups, usually through regulations that have significant implications for business operations. Understanding these regulations and their impacts is a challenge, because they are relatively new.

- Most regulations were conceived with a view to protecting the rights of workers and the environment, and present liabilities to a company if they are not observed. A proper understanding of these regulations and identifying their impacts is necessary, as non-adherence can detract from a company's image and may cause loss of goodwill from current and potential clients.

- Different environmental performance standards are being put into place by governments, especially relating to new areas, such as eco-management and eco-monitoring schemes. This is a challenging task.

- How to identify possible gains and benefits from practising these new ecostandards is relatively poorly understood.

- Developing a balancing strategy to ensure business commitment to corporate social responsibility and maximising shareholder value is a major challenge, because it has yet to be adequately studied.

\section{Major business ĩnitiatives}

Some businesses have made inroads in trying to incorporate sustainable development initiatives into their normal operations, especially members of WBCSD. These initiatives include the following:

- Eco-efficiency implies producing more with less resources and less pollution, and encourages business to be more competitive, more innovative and more environmentally responsible.

- Environmental accounting reflects the environmental costs of trade and industrial operations in the accounts of business and, consequently, those of countries.

- Improved management practices include waste minimisation and resource optimisation in products and processes; developing sustainable development products, changing manufacturing processes to reflect sustainable development concerns, and environmental and social accounting.

- Business charters and principles mean agreement by big companies to conform to set principles to operate in a socially and environmentally responsible way. 
- Environmental management systems (EMS) are internationally agreed standards based on improvement of quality of product and services, and provide valuable assurances for clients. This initiative is particularly important because of its wide use, and requires further discussion.

\section{Environmental management systems}

EMS emerged from the British Standards Institution environmental management systems standard, BS 7750. Along with this, the WBCSD members developed a range of EMS standards that emerged through the International Organisation for Standardisation (ISO), which led to the ISO 14000 series. The ISO 14000 did not set specify environmental performance levels but used a management system approach similar to the ISO 9000 quality standards to promote environmental performance.

EMS is generally a group of policies, standards, systems and tools that assist the effectiveness of the business in coping with environmental concerns. EMS can be very important for good decision-making. In practice, it should be fully integrated in all functions of business operations and ensure that they are consistent with sustainable development principles. The main areas of incorporating EMS in business may include siting, construction and operation of the business; employee performance evaluation; product and process design and modification; materials procurement and supplies; information and business management; and internal and external communications. Benefits to companies include savings (freedom from liabilities) resulting from complying with regulations; an improved image, leading to increased goodwill among stakeholders; resource conservation and capital savings; and market advantage and increased market confidence.

\section{Business in developing countries}

Generally, exploiting most of the market potential in developing countries, particularly in the least developed countries, will require overcoming some of the major inadequacies in these countries that are not necessarily conducive to good business operations. In most of these countries, a large proportion of the people are in a poverty trap, and the economic growth of the country is either negative or very low, thus limiting domestic resource mobilisation. Official capital flows to these countries are also, therefore, limited. Recent trends show that private capital flows hardly go to poor countries. For the past decade or so, for example, about 11 middle-income countries have attracted over 75 per cent of foreign direct investments. Since the dwindling overseas development assistance funding generally follows similar paths, poor countries get very little funding - either private or official. 
Many investors fail to invest in poor countries because of perceived risks, including a high degree of vulnerability to external political and economic shocks, weak social infrastructure, the smallness of the market, and a poor business environment. The last of these is particularly important, and demands urgent attention if developing countries are to attract entrepreneurs.

\section{Creating a business environment}

A satisfactory business environment is crucial to attract private funding and foreign business, including those that want to develop partnerships with either local businesses or governments in trying to overcome some of the problems outlined above.

- Setting up an institutional, legislative and regulatory framework environment is important, so that business enterprises are fully aware of the mode of operation in a country. In many least developed countries, the institutional base is fragmented and unclear, and functions and functional relationships within institutions are confusing. In a few cases there may be a need for innovative institutions to cope with the demands for an adequate business environment. In forming such an environment, however, the use of indigenous effort should be maximised because this will assist in developing standards and regulations that reflect and are suited to local conditions.

- Lack of capacity has been identified as a major problem in these countries, and formal and informal training schemes for targeted programmes, including needs assessment and business development, can prove extremely useful. Ensuring retention of trainees is an important aspect of such programmes.

- Businesses should cooperate with local agencies to undertake useful research and development and demonstration programmes that will support business development.

- In many developing countries, rationalisation of prices is required to foster a business-friendly environment, and this can be done by reducing distortion in the tax system and promoting targeted subsidies for the poor, to address social concerns.

- Information development using all modern electronic systems, especially the development and promotion of business information is important. The lack of institutions providing business services suggests the need for setting up business intermediaries, to help promote business information.

- Where countries in a region are small and fragmented, regional cooperation and coordination are important to maximise the benefits of business. This can be achieved by promoting different networks, harmonisation of standards and promotion of business forums. 
Changes needed in business operations

Business enterprises need to change their perspectives to take advantage of the potential outlined earlier. These changes include the following:

- Businesses should view governments as partners of development and not as an avenue for exploiting subsidies.

- Regulations should be considered as setting targets for establishing a framework of operation to ensure environmental protection, and not as dictating operating guidelines.

- Long-term relations with different stakeholders of development should be promoted because they are crucial for achieving long-term benefits of sustainable development.

- Businesses should assist in stimulating market promotion schemes to help poor countries to move away from aid dependency, and towards participation in commercial operations.

\section{CONCLUSIONS}

There is a large international market for goods and services produced using the principles of sustainable development, but exploiting it will require the business sector to improve its understanding of this new market, especially in developing countries. Promoting market development in some countries in the short run requires development of new partnerships and nurturing the local cooperate sector, but long-term gains can be substantial. Businesses should realise that becoming involved in sustainable development goes beyond maximising shareholder value, and includes demonstrating heightened responsibilities towards its workers, customers and society. 